\title{
Vapor phase Beckmann rearrangement using high silica zeolite catalyst
}

\author{
L. Forni, ${ }^{a}$ G. Fornasari, ${ }^{a}$ G. Giordano, ${ }^{b}$ C. Lucarelli, ${ }^{a}$ A. Katovic, ${ }^{b}$ F. Trifirò,${ }^{a}$ \\ C. Perri $^{c}$ and J. B. Nagy ${ }^{c}$ \\ ${ }^{a}$ Dep. Chemical Industry and Materials, University of Bologna, V.le Risorgimento 4, \\ I-40136 Bologna, Italy.E-mail:forni@ms.fci.unibo.it; fornasar@ms.fci.unibo.it; \\ c_lucarelli@libero.it; trifiro@ms.fci.unibo.it; Fax: +39-051-2093680; \\ Tel: +39-051-2093677 \\ ${ }^{b}$ Dep. Chemical Engineering and Materials, University of Calabria, Via Bucci, \\ I-87030 Rende (CS), Italy.E-mail: ggiorda@unical.it; katovic@unical.it \\ c NMR Laboratory, University of Namur, rue de Bruxelles 61, B-5000 Namur, Belgium. \\ E-mail: janos.bnagy@fundp.ac.be
}

Received 23rd December 2003, Accepted 4th February 2004

First published as an Advance Article on the web 9th March 2004

\begin{abstract}
Vapor phase Beckmann rearrangement of cyclohexanone oxime to $\varepsilon$-caprolactam has been studied using high silica zeolite catalysts. Catalysts with different crystal sizes and gel-ageing times have been activated by ionic exchange in different conditions by means of a highly basic solution and a nearly neutral solution both containing ammonium salts. Samples have been calcined at different temperatures in order modify the number of defective sites. We observed that samples exchanged by means of a highly basic solution $(\mathrm{pH}>10)^{1,2}$ and calcined at a relatively lower temperature $\left(450^{\circ} \mathrm{C}\right)$ show the most interesting catalytic results. X-ray powder diffraction patterns of these samples show ${ }^{2}$ retention of the unit cell symmetry (orthorhombic cell) if compared to the dried sample. $\mathrm{NH}_{3}$-TPD confirms the low acidity of high silica zeolites, however a higher amount of desorbed ammonia is observed for the samples exchanged at higher $\mathrm{pH}$ and calcined at $450^{\circ} \mathrm{C}$. Due to silanol nests the IR spectra of the same samples show the formation of $\mathrm{Si}-\mathrm{NH}_{2}$ bonds which are absent in the same material exchanged by other methods. Such sites seem to promote the high stability of the high silica zeolite catalysts also to the regeneration which is needed to remove the heavy carbonaceous compounds from the catalyst surface.
\end{abstract}

\section{Introduction}

The last step of caprolactam commercial production is obtained, nowadays, in liquid phase by means of Beckmann rearrangement of cyclohexanone oxime, with oleum as promoter. Such a process is energy consuming and co-produces stoichiometric ammonium sulfate quantities. ${ }^{3}$ Thus driving forces of new researches are the tuning of alternative paths with a lower environmental impact (no ammonium sulfate production and no sulfuric acid use) and energy saving (lower number of steps of reaction and decrease of the volume of solvents used). ${ }^{5-7}$ The first researches started in the sixties but only recently Sumitomo Inc. found that high siliceous silicalites, a peculiar MFI structure, are highly active and selective towards Beckmann rearrangement in vapor phase. ${ }^{4,8}$ Said catalysts show long-lasting tests and for this reason a $5000 \mathrm{t}^{\text {year }}{ }^{-1}$-demonstration plant has been started, however by the end of year 2003 the build-up of a production plant, in Japan, has been announced. ${ }^{9}$ Main physicochemical characteristics of high-silica silicalites are silanol nests which contribute, with a relatively low acidity, to the good selectivity of the final product. ${ }^{8,10}$ Even though recent papers describe the possible reaction mechanism of cyclohexanone oxime on high siliceous silicalites ${ }^{8}$ little is still available on the reaction mechanism. In the present work we study the effect of physico-chemical parameters of silicalite-1 catalyst on the vapor phase Beckmann rearrangement. We investigate on the role of structural defective sites and crystal dimensions on caprolactam selectivity and the effect of acid sites distribution on catalytic performances. This work focuses, especially, on the understanding of the effect of the activation method on the structural arrangement of silicalite- 1 and on its catalytic performances. One of the methods we applied induces a different unit cell geometry organization and a different acid site distribution.

\section{Experimental}

High silica MFI zeolite materials were prepared according to procedures reported in literature. ${ }^{11}$ Four samples with different crystal sizes $(2.5 \mu \mathrm{m}, 10 \mu \mathrm{m}, 30-50 \mu \mathrm{m}$ and $70 \mu \mathrm{m})$ were studied in detail. The samples were calcined at two different temperatures: lower temperature (about $450^{\circ} \mathrm{C}$ ) and higher temperature (about $550^{\circ} \mathrm{C}$ ). Then they were activated, to get the protonic form, using $\mathrm{NH}_{4} \mathrm{Cl}$ or alkaline- $\mathrm{NH}_{4} \mathrm{NO}_{3}$ solution by usual procedure. Catalysts were characterized by means of different techniques. Catalyst texture was determined by nitrogen adsorption at $-176^{\circ} \mathrm{C}$ with a Micrometrics Porosimeter ASAP 2010 after treatment of the samples at $200^{\circ} \mathrm{C}$ under vacuum. X-ray powder diffraction (XRD) was carried out by a Philips X'pert Pro diffractometer between 4 and $40^{\circ}$ $2 \theta$ angle. IR spectra were obtained on a Nicolet Nexus FTIR spectrometer equipped with a $\mathrm{MCT}(\mathrm{Hg} / \mathrm{Cd} / \mathrm{Tl})$ detector being the IR source made of CSi. Solid state Magic Angle Spinning (MAS-NMR) spectroscopy was used to characterize the local $\mathrm{Si}$ environments in the samples. Spectra were recorded on a Bruker MSL 400 spectrometer working at 79.4 $\mathrm{MHz}\left({ }^{29} \mathrm{Si}\right)$ a pulse length of $6 \mu \mathrm{s}$ and a repetition time between acquisition of $60 \mathrm{~s}$, the reference at $0 \mathrm{ppm}$ being taken as 
$\mathrm{Si}\left(\mathrm{CH}_{3}\right)_{4}$ (TMS). Cross-polarization NMR (CP-NMR) was performed in the same MAS-NMR conditions with a contact time of $5 \mathrm{~ms}$. $\mathrm{NH}_{3}$-Temperature programmed desorption $\left(\mathrm{NH}_{3}\right.$-TPD) was carried out on a 1100 Thermofinnigan $\mathrm{TPD} / \mathrm{RO}$ instrument, the catalyst was pre-treated from 20 to $450^{\circ} \mathrm{C}$ with an isotherm at $450^{\circ} \mathrm{C}$ for $60 \mathrm{~min}$ and adsorption occurred at $100^{\circ} \mathrm{C}$ followed by desorption step from 100 to $450^{\circ} \mathrm{C}$ at a rate of $10 \mathrm{deg} \mathrm{min}^{-1}$.

Beckmann rearrangement of cyclohexanone-oxime to caprolactam was carried out in a glass fixed-bed microreactor, packed with inert material (glass spheres). The reaction temperature ranged between $300^{\circ} \mathrm{C}$ and $400^{\circ} \mathrm{C}$ and weight hourly space velocity (WHSV) was $1.2 \mathrm{~h}^{-1}$. A solution of cyclohexanone-oxime, methanol and toluene, in a flow of nitrogen, was utilized as the feed. The products were determined by gas chromatography.

\section{Catalyst preparation}

The investigated catalysts were prepared according to the composition reported in Table 1.

The samples were calcined in order to eliminate the template. After calcination they were exchanged by aqueous solutions in order to obtain the protonic form and finally calcined again to stabilize the structure. The catalyst nomenclature is arranged according to three numbers $(x y x)$; the first number refers to the calcination temperature $\left(1=450^{\circ} \mathrm{C}, 2=\right.$ $550^{\circ} \mathrm{C}$ ), the second number indicates the aqueous exchange solution $\left(1=\mathrm{NH}_{4} \mathrm{NO}_{3}, \quad 2=\mathrm{NH}_{4} \mathrm{Cl}\right)$, the third number represents the last calcination temperature which is always the same as the first one. Thus, for example, catalyst 1793-212 has been calcined at $550^{\circ} \mathrm{C}$ and exchanged by a $\mathrm{NH}_{4} \mathrm{NO}_{3}$ solution. The different activation solutions are characterized by a relevant $\mathrm{pH}$ difference, $\mathrm{pH}>9$ for $\mathrm{NH}_{4} \mathrm{NO}_{3}$ and $\mathrm{pH}=7$ for $\mathrm{NH}_{4} \mathrm{Cl}$.

Table 1 Silicalite-1 composition and crystal size. TPABr: tetrapropylammoniumbromide

\begin{tabular}{lll}
\hline Catalyst & Starting gel composition & $\begin{array}{l}\text { Crystallite } \\
\text { diameter }\end{array}$ \\
\hline 1792 & $0.08 \mathrm{Na}_{2} \mathrm{O}-0.08 \mathrm{TPABr}-1 \mathrm{SiO}_{2}-20 \mathrm{H}_{2} \mathrm{O}$ & $10 \mu \mathrm{m}$ \\
1793 & $0.08 \mathrm{Na}_{2} \mathrm{O}-0.08 \mathrm{TPABr}-1 \mathrm{SiO}_{2}-20 \mathrm{H}_{2} \mathrm{O}$.Gel & $2.5 \mu \mathrm{m}$ \\
& ageing for 5 days at room temperature. & \\
1795 & $0.04 \mathrm{Na}_{2} \mathrm{O}-0.08 \mathrm{TPABr}-1 \mathrm{SiO}_{2}-20 \mathrm{H}_{2} \mathrm{O}$ & $30-50 \mu \mathrm{m}$ \\
1796 & $0.02 \mathrm{Na}_{2} \mathrm{O}-0.08 \mathrm{TPABr}-1 \mathrm{SiO}_{2}-20 \mathrm{H}_{2} \mathrm{O}$ & $70 \mu \mathrm{m}$ \\
\hline
\end{tabular}

\section{Results and discussion}

\section{Catalyst physical-chemical properties}

By means of X-ray powder diffraction we observed the typical silicalite-1 pattern. All dried samples show reflections attributed to the template molecules and a single reflection at $24.4^{\circ}$ $2 \theta$ angle typical of the silicalite- 1 orthorhombic unit cell. After calcination we observe a double reflection, at the same $2 \theta$ angle, attributed to a change of the unit cell towards a monoclinic symmetry which is thermally more favored than the previous one ${ }^{12}$ as reported in Fig. 1.

All catalysts retain monoclinic symmetry, but after activation the samples calcined at $450{ }^{\circ} \mathrm{C}$ and treated by an alkaline $\mathrm{NH}_{4} \mathrm{NO}_{3}$ solution modify again the unit cell towards an orthorhombic symmetry. While the samples activated by a $\mathrm{NH}_{4} \mathrm{Cl}$ solution maintain the monoclinic symmetry. In Fig. 2 we display the unit cell evolution of the same sample after different thermal treatments and activation procedures. The same behavior as Fig. 2 is observed for all samples (1792, 1793, 1795, 1796).

We suggest that thermal treatment at $450{ }^{\circ} \mathrm{C}$ followed by exchange with a $\mathrm{NH}_{4} \mathrm{NO}_{3}$ alkaline solution promotes a structural rearrangement towards an orthorhombic unit cell symmetry which usually is less favored thermally, in silicalite-1 materials, than the monoclinic one. As a matter of fact by FT-IR spectroscopy we verify that all samples calcined at $450{ }^{\circ} \mathrm{C}$ and activated by the $\mathrm{NH}_{4} \mathrm{NO}_{3}$ alkaline solution (-111 samples) show a band at $953 \mathrm{~cm}^{-1}$ typical of $\mathrm{Si}-\mathrm{N}$ stretching mode, ${ }^{13}$ as shown in Fig. 3 .

The $\mathrm{Si}-\mathrm{NH}_{2}$ bond is characterized by other vibrations at 3540 and $3450 \mathrm{~cm}^{-1}$ which are probably hidden by the wide band between 3600 and $3200 \mathrm{~cm}^{-1}$. The band at about 953 $\mathrm{cm}^{-1}$ is typical of $\mathrm{Si}-\mathrm{O}-\mathrm{M}$ (where $\mathrm{M}=$ heteroatom) vibration, ${ }^{14}$ and in silicalite- 1 this vibration could be also attributed to the $\mathrm{Si}-\mathrm{O}-\mathrm{Na}$ bond which yet is not present in activated samples as the -111 catalysts. Hence, FT-IR spectra of samples exchanged by a $\mathrm{NH}_{4} \mathrm{Cl}$ solution $(-121)$ do not show such a vibration, see Fig. 3b, this result further confirms our findings.

The evaluation of $\mathrm{OH}$ stretching signals shows one broad band with maximum at $3400 \mathrm{~cm}^{-1}$ and a shoulder at 3617 $\mathrm{cm}^{-1}$ and one IR signal at $3723 \mathrm{~cm}^{-1}$. These bands are attributed, according to the literature, ${ }^{5,15}$ to nests of silanols, bridged hydroxyl and terminal silanols, respectively. We also investigated the $\mathrm{Si}$ chemical neighborhood by solid state NMR spectroscopy. By ${ }^{29} \mathrm{Si}$ MAS-NMR we were able to distinguish the defective sites from the perfect tetrahedral $\mathrm{SiO}_{4}$, These defective sites represent a small percentage of total silicon atoms present in the lattice. As a matter of fact we measured a maximum of 8 defective sites per unit cell with

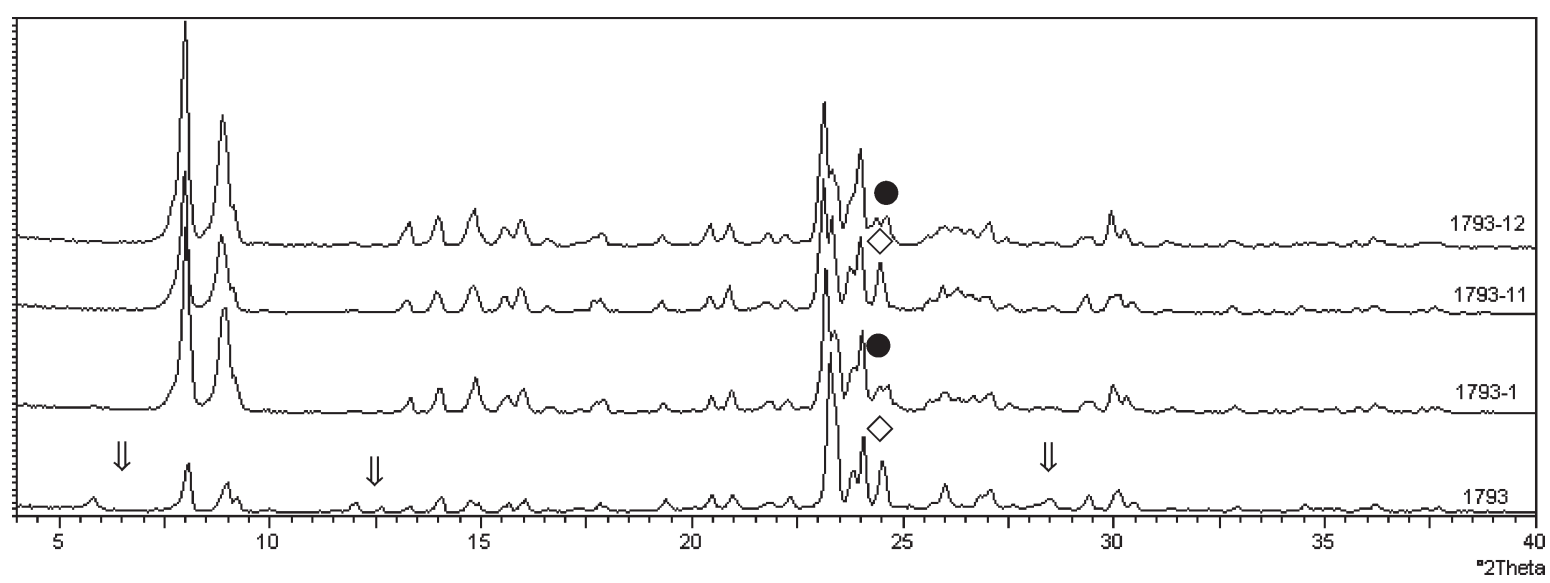

Fig. 1 XRD pattern of 1793 catalyst: evolution upon thermal treatment and activation method to obtain silicalite-1 protonic form. $\Downarrow$ template, $\diamond$ orthorhombic, $\bullet$ monoclinic cell. 


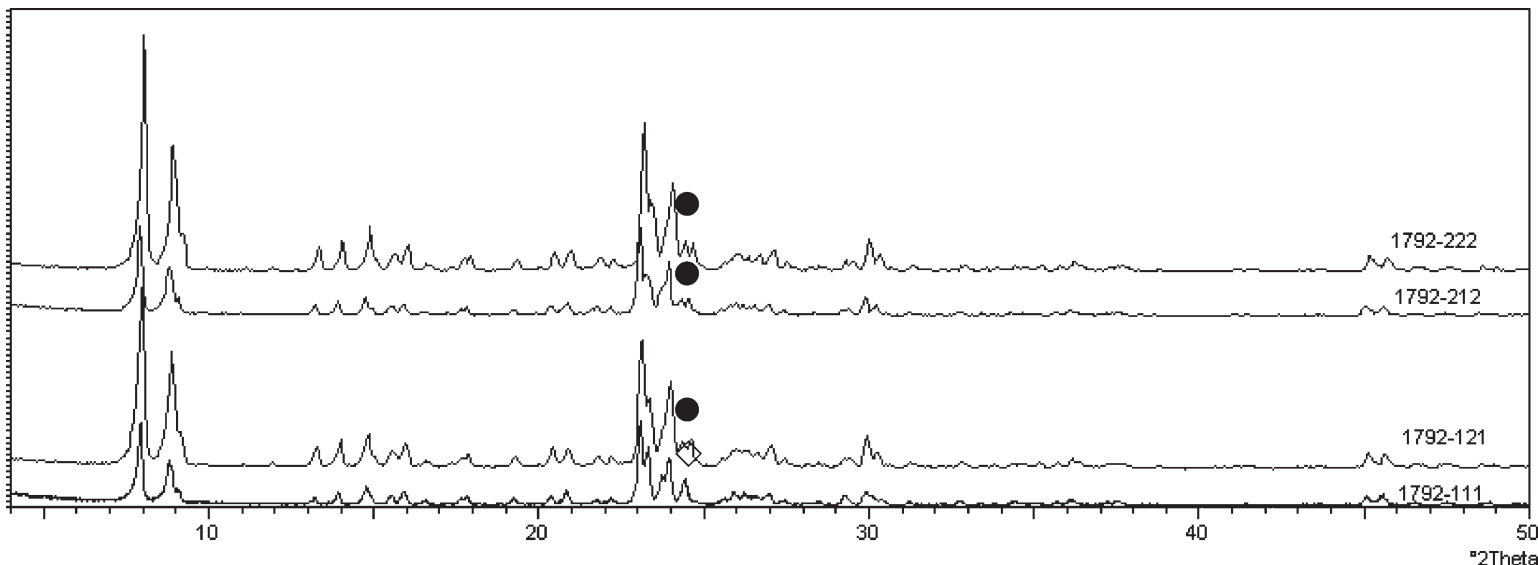

Fig. 2 XRD patterns for catalyst 1792 after calcination and activation, $\diamond$ orthorhombic, $\bullet$ monoclinic.

respect to the 32 theoretical defective sites of silicalite- 1 unit cell. ${ }^{29} \mathrm{Si}$ MAS-NMR shows a higher defective sites percentage for samples calcined at $450^{\circ} \mathrm{C}$ and activated by alkaline $\mathrm{NH}_{4} \mathrm{NO}_{3}$ solution. However using ${ }^{29} \mathrm{Si}-\mathrm{CP}-\mathrm{NMR}$ we could detect two different kinds of defective sites. The first one with a chemical shift of $-93 \mathrm{ppm}$ is attributed to terminal silanols, the second one at $-103 \mathrm{ppm}$ is related to nests of silanols or bridegd silanols. While $-113 \mathrm{ppm}$ is the chemical shift of $\mathrm{SiO}_{4}$ groups. Such sites are represented in Fig. 4.

By ${ }^{29} \mathrm{Si}-\mathrm{CP}-\mathrm{NMR}$ analysis we detected, in general, a higher amount of $\mathrm{H}$ - bonded silanols, with chemical shift at -103 ppm, than terminal silanols at $-93 \mathrm{ppm}$. In addition, regardless of calcination temperatures, samples activated by the alkaline $\mathrm{NH}_{4} \mathrm{NO}_{3}$ solution show a higher $\mathrm{H}$-bonded silanol percentage. Samples with the same active site amount, but treated with $\mathrm{NH}_{4} \mathrm{Cl}$, are characterized by a lower $\mathrm{H}$-bonded silanol percentage than samples treated with $\mathrm{NH}_{4} \mathrm{NO}_{3}$. For example, both 1792-212 and 1792-222 samples have three defective sites per unit cell, however the ratio between $\mathrm{H}$-bonded silanols and terminal silanols is 10.6 and 1.52 , respectively.

In table 2 we report the percentage of defects per unit cell and the ratio between $\mathrm{H}$-bonded silanols and terminal silanols, this ratio represents a relative value for it is referred to the percentage of defective sites per unit cell.

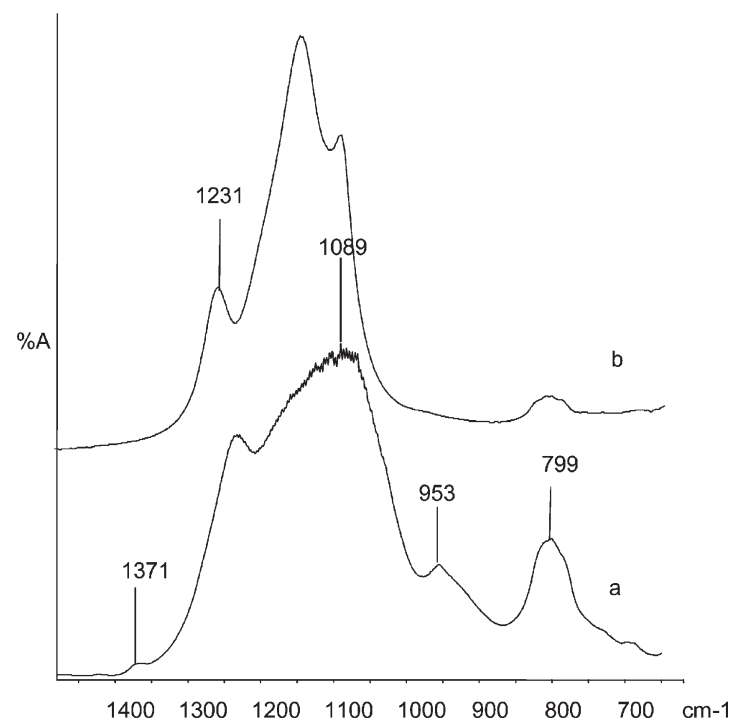

Fig. 3 FT-IR of silicalite- 1 sample (a) after calcination at $450{ }^{\circ} \mathrm{C}$ and activation by a $\mathrm{NH}_{4} \mathrm{NO}_{3}$ solution $(\mathrm{pH}>10)$ (b) after calcination at $450{ }^{\circ} \mathrm{C}$ and activation by a $\mathrm{NH}_{4} \mathrm{Cl}$ solution $(\mathrm{pH} \approx 8)$. The band at $953 \mathrm{~cm}^{-1}$ represents the stretching of $\mathrm{Si}-\mathrm{NH}_{2}$ bondings.
Since samples treated at $450^{\circ} \mathrm{C}$ and activated by a $\mathrm{NH}_{4} \mathrm{NO}_{3}$ alkaline solution show a different crystallographic unit cell (orthorhombic symmetry) and a higher defective sites and $\mathrm{H}$-bonded silanols distribution, we suggest that: (i) calcination temperature has a determinant effect on the total number of defective sites (higher calcinations temperatures promote silanols condensation, with elimination of $\mathrm{H}_{2} \mathrm{O}$ molecules), (ii) the $\mathrm{pH}$ of the $\mathrm{NH}_{4} \mathrm{NO}_{3}$ solution is of basic importance for the formation of $\mathrm{H}$-bonded silanols for $\mathrm{NH}_{3}$ reacts with $\mathrm{Si}-\mathrm{O}-\mathrm{Si}$ bonds to give $\mathrm{Si}-\mathrm{NH}_{2}$ groups (as demonstrated by IR-spectroscopy).

Terminal and H-bonded silanols, according to literature ${ }^{5,16}$ determine the acidity of silicalite- 1 materials whose peculiarity is the presence of weak Brønsted acid sites. By $\mathrm{NH}_{3}$-TPD we determined the strength, the amount and distribution of Brønsted acid sites (Figs. 5 and 6).

We observe three peaks. Two of them are observed during temperature rate, in the region between $180-200^{\circ} \mathrm{C}$ and 250 $300^{\circ} \mathrm{C}$, respectively. The third one is located in the isothermal zone at $450^{\circ} \mathrm{C}$ and is caused by diffusion phenomena and can be ascribed to the peak at $250-300^{\circ} \mathrm{C}$. Hence we attribute the peaks to terminal silanols (very weak acid sites) and $\mathrm{H}$-bonded

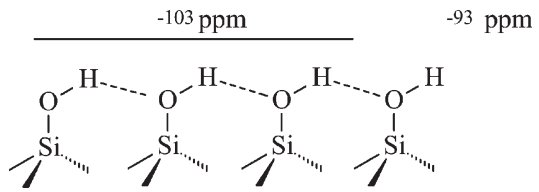

Fig. 4 Scheme representing the silanols groups detected by ${ }^{29} \mathrm{SiCP}-$ NMR spectroscopy.

Table 2 Percentage of defects per unit cell and H-bonded $v s$. terminal silanol ratio

\begin{tabular}{lllrc}
\hline & $\begin{array}{l}\text { Defective } \\
\text { sites per unit } \\
\text { cell } I(\%)\end{array}$ & $I_{-103 \text {,H-bonded }}$ & $I_{-93, \text { terminal }}$ & $\begin{array}{l}I_{\text {H-bonded }} / \\
\text { Sample }\end{array}$ \\
\hline $1793-111$ & 4 & 33 & 1 & 33.0 \\
$1793-121$ & 3 & 48 & 14 & 3.4 \\
$1793-212$ & 3 & 54 & 7 & 7.7 \\
$1793-222$ & 1 & 34 & 14 & 2.4 \\
$1792-111$ & 8 & 50 & 8 & 6.2 \\
$1792-121$ & 3 & 42 & 20 & 2.1 \\
$1792-212$ & 3 & 53 & 5 & 10.6 \\
$1792-222$ & 3 & 41 & 27 & 1.5 \\
$1795-111$ & 6 & 48 & 3 & 24.0 \\
$1795-212$ & 4 & 57 & & 19.0 \\
\hline
\end{tabular}




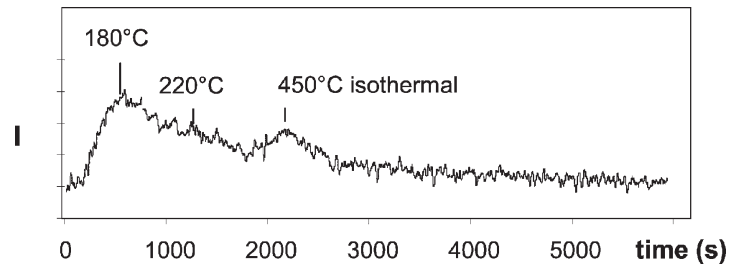

Fig. $5 \mathrm{NH}_{3}$-TPD profiles for silicalite-1 catalyst treated at $450{ }^{\circ} \mathrm{C}$ with $\mathrm{NH}_{4} \mathrm{NO}_{3}$ alkaline solution.

silanols (weak acid sites), respectively, in agreement with the NMR results.

In Table 3 we report the total amount of desorbed ammonia per gram of catalyst and an evaluation of acid site distribution.

We observe low total acidity for all catalysts, however the samples treated at $450{ }^{\circ} \mathrm{C}$ and activated by a $\mathrm{NH}_{4} \mathrm{NO}_{3}$ alkaline solution (-111 samples) are characterized by a higher total acidity than the same samples treated in the other conditions. In addition, the evaluation of acid site distributions, on the basis of the areas of the peaks distinguished by TPD profiles shows, for all samples, a higher amount of weak acid sites (H-bonded silanols) with respect to very weak acid sites (terminal silanols). Said distribution is especially remarkable for the -111 catalysts, this result is in agreement with the NMR data.

In particular, sample 1793-111 shows a relative higher acidity, when compared to other 1793 catalysts, the first TPD peak (terminal silanols) has its maximum at $180^{\circ} \mathrm{C}$, while a shoulder attributed to $\mathrm{H}$-bonded silanols is detected at $290{ }^{\circ} \mathrm{C}$. $1793-212$ is characterized by the same behavior as sample 1793-111, however it shows a lower acidity which, according to Zecchina et al. ${ }^{15}$ may be attributed to the decrease of stronger vicinal silanols because of the higher number of hydroxyl-group condensations during calcination at $550^{\circ} \mathrm{C}$. Catalysts $1793-222$ has a higher percentage of very weak silanols, such a result is related to the higher calcinations temperature which is responsible for the decrease of the number of defective sites, and by the method of catalyst activation. This hypothesis is supported by the decrease of total number of silanol groups and by the higher percentage of terminal-OH groups in sample 1793-121 than in 1793-111. These results are confirmed also by the characterization of the other samples. Sample 1796 shows the same silanol distributions observed for the other materials, but its acidity is consistently lower. This is caused by the low number of defective sites which are affected by the low mineralizing agent quantity $\left(\mathrm{Na}_{2} \mathrm{O}\right)$ used during its preparation.

\section{Catalytic activity}

Crystal dimensions play an important role on the Beckmann rearrangement catalytic activity of silicalite-1. For this reason four catalysts 1792-111, 1793-111, 1795-111, 1796-111 with different crystal sizes were tested in the reaction at the conditions reported in the experimental section at $T=300^{\circ} \mathrm{C}$. Cyclohexanone oxime conversion and caprolactam selectivity are reported in Fig. 7 as a function of crystal size.

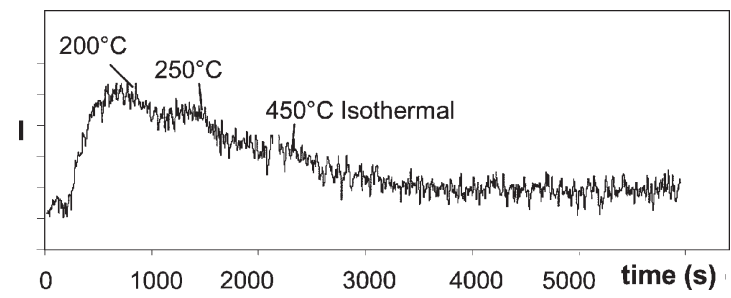

Fig. $6 \mathrm{NH}_{3}$-TPD profiles for silicalite-1 catalyst treated at $550^{\circ} \mathrm{C}$ with $\mathrm{NH}_{4} \mathrm{Cl}$ alkaline solution.
Table 3 Total catalyst acidity and acid site distribution, very weak (terminal silanols) and weak (H-bonded) silanols

\begin{tabular}{llll}
\hline & $\begin{array}{l}\text { Acidity } / 10^{-5} \\
\times \mathrm{mol} \mathrm{NH}_{3} \mathrm{~g}^{-1}\end{array}$ & $\begin{array}{l}\text { Very weak } \\
\text { acid sites }(\%)\end{array}$ & $\begin{array}{l}\text { Weak acid } \\
\text { sites }(\%)\end{array}$ \\
\hline $1793-111$ & 7.15 & 25 & 75 \\
$1793-121$ & 5.53 & 35 & 65 \\
$1793-212$ & 5.07 & 30 & 70 \\
$1793-222$ & 5.30 & 39 & 61 \\
$1792-111$ & 7.43 & 20 & 80 \\
$1792-121$ & 7.00 & 30 & 70 \\
$1792-212$ & 5.63 & 27 & 73 \\
$1792-222$ & 4.02 & 32 & 68 \\
$1795-111$ & 7.80 & 28 & 72 \\
$1795-212$ & 5.86 & 35 & 65 \\
$1796-111$ & 4.92 & 22 & 78 \\
$1796-121$ & 4.55 & 27 & 73 \\
$1796-222$ & 2.19 & 30 & 70 \\
\hline
\end{tabular}

Cyclohexanone oxime conversion reaches a maximum (90\%) for sample 1793-111 with the lowest crystal size $(2.5 \mu \mathrm{m})$ and undergoes a substantial decrease with increasing crystal dimension. A different behavior is observed for caprolactam selectivity, the minimum value $(90 \%)$ is observed for catalyst with crystals size $2.5 \mu \mathrm{m}$ (1793-111), then the selectivity increases progressively to achieve $100 \%$ with sample 1796-111. These results are attributed to the different distribution of silanols on the internal and external catalyst surface. Beckmann rearrangement to caprolactam is promoted by H-bonded silanols which, according to Zecchina and Dalloro, ${ }^{5,15}$ are located in the internal surface of the crystals, while terminal silanols which are mainly distributed in the external surface affect the non-selective conversion of cyclohexanone oxime. As a matter of fact by increasing crystal size dimensions, the ratio between internal/external surface increases, thus a higher number of $\mathrm{H}$ bonded sites are available for the selective conversion of cyclohexanone oxime. Hence sample with the lowest crystal size dimension $(2.5 \mu \mathrm{m})$ displays the higher conversion but the lower caprolactam selectivity because of the relative higher amount of terminal silanols with respect to the amount of $\mathrm{H}$-bonded silanols. We observed the formation of the following by-products: cyclohexanone, cyclohexen-1-one, trans penten-nitrile, aniline whose selectivities are rather low and have a value, for each component, set around $1-2.5 \%$.

The same cyclohexanone oxime conversion behavior is observed also for catalysts -222 (1792-222, 1793-222, 1796222), its values are always lower than $35 \%$ as illustrated in Fig. 8.

On the contrary, caprolactam selectivity shows a different behavior, with increasing crystal size a decrease of caprolactam selectivity is observed and the same behavior is shown by -121 and -222 samples. Usually caprolactam selectivity values are

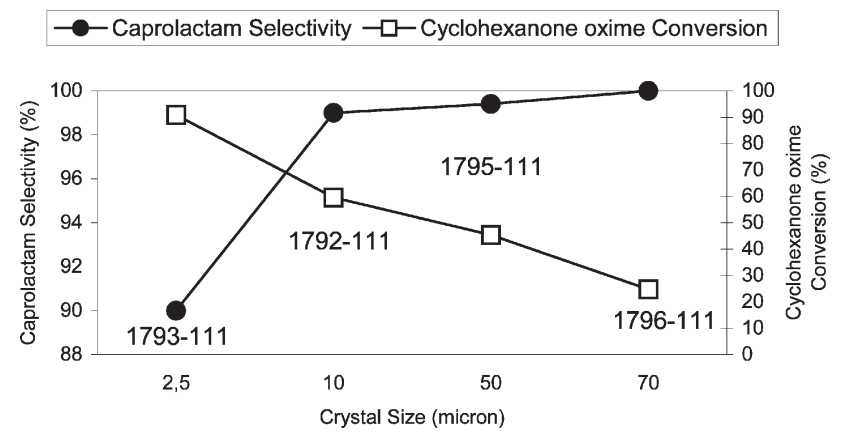

Fig. 7 Cyclohexanone oxime conversion and caprolactam selectivity values as a function of crystal size for catalysts prepared according to -111 method. Values are referred to the fourth hour of reaction. 
Caprolactam Selectivity $\neg-$-Cyclohexanone oxime Conversion

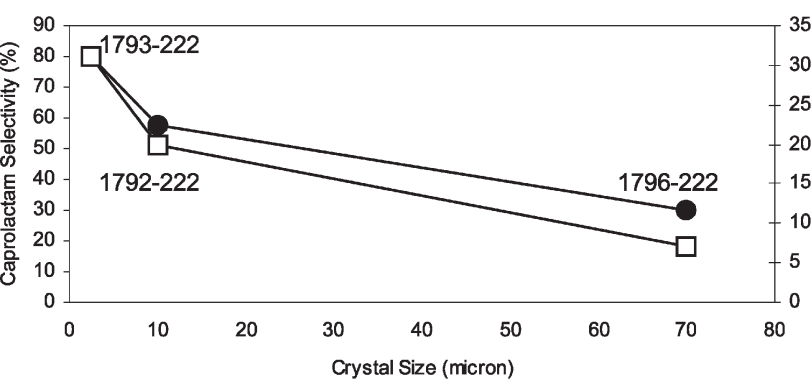

Fig. 8 Cyclohexanone oxime conversion and caprolactam selectivity values as a function of crystals size for catalysts prepared according to -222 method. Values are referred to the fourth hour of reaction.

much lower than those obtained on catalysts -111 , as a matter of fact, the highest value for -222 samples $(80 \%)$ is observed for catalyst $1793-222$, the other catalysts show remarkably low caprolactam selectivity values (about $58 \%$ for $1792-222$ and $30 \%$ for 1796-222). The results for the -222 series are in good agreement with those of Weitkamp et al. ${ }^{17}$ and are attributed to the high calcination temperatures, which cause the condensation of a higher number of silanols by elimination of water molecules. Hence the number of defective sites decreases but the catalyst is also less activated by the use of an almost neutral $\mathrm{NH}_{4} \mathrm{Cl}$ solution. The different behavior of selectivity may be explained by a different acid site distribution between the external and internal surfaces, due to the different treatments of samples. The good catalytic activity observed for catalysts -111 has to be ascribed mainly to the activation with a $\mathrm{NH}_{4} \mathrm{NO}_{3}$ solution for it is able to modify silicalite-1 structure and promotes a higher $\mathrm{H}$-bonded silanol amount than terminal silanols, as reported in table 3.

Silanols distribution plays an important role in catalyst acidity thus we carried out some tests in order to relate the catalytic behavior to samples acidity. We compared the catalytic results obtained on the 1793 samples series. In Fig. 9 we report cyclohexanone oxime conversion and the caprolactam selectivity as a function of catalyst total acidity.

Apparently no linear correlation occurs between sample total acidity and catalytic performance, however it is possible to point out two couples of data which are better reciprocally correlated.

Samples calcined at the same temperature (1793-212, 1793222 at $550^{\circ} \mathrm{C}$ and $1793-111,1793-121$ at $450^{\circ} \mathrm{C}$ ) and activated by $\mathrm{NH}_{4} \mathrm{NO}_{3}$ alkaline solution and $\mathrm{NH}_{4} \mathrm{Cl}$ neutral solution, respectively, show different results. Catalyst 1793-212 is characterized by higher catalytic performances than 1793-222. The same behavior is observed also for catalysts 1793-111 and 1793-121 but the catalytic results are much improved. We verify that the activation by a $\mathrm{NH}_{4} \mathrm{NO}_{3}$ alkaline solution

Caprolactam Selectivity $-\square-$ Cyclohexanone oxime Conversion

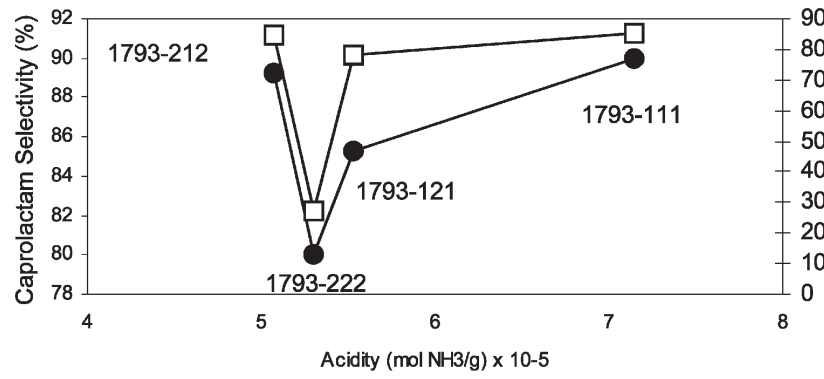

Fig. 9 Catalytic performances of catalyst 1793 as a function of total acidity. Values are referred to the fourth hour of reaction.

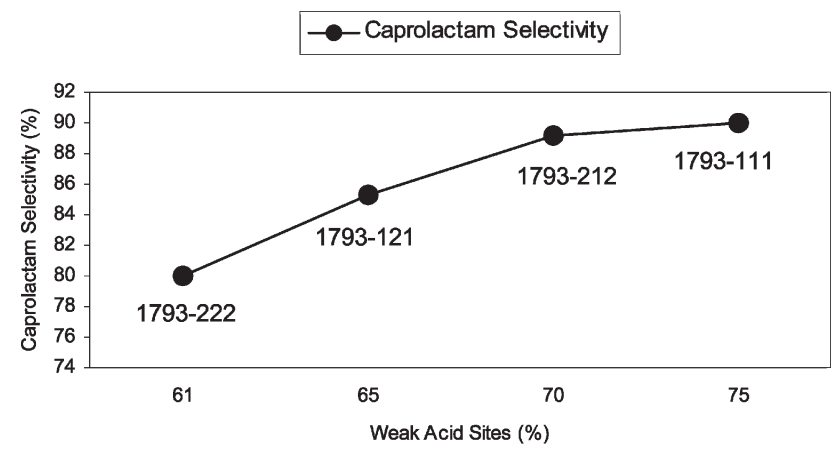

Fig. 10 Catalytic performances of catalyst 1793 as a function of weak H-bonded silanols distribution. Values are referred to the fourth hour of reaction.

improves catalysts physico-chemical properties and leads to better catalytic performances. On the contrary, the increase of calcinations temperature decreases the total acidity and also catalytic performances.

In Fig. 10 we report caprolactam selectivity as a function of the amount of H-bonded silanol groups.

By increasing $\mathrm{H}$-bonded silanol percentage we observe an increase of caprolactam selectivity from a value of $80 \%$ (1793-222) to $90 \%$ (1793-111). These results confirm that active sites towards caprolactam formation are H-bonded silanols, which are located in the internal surface of the catalyst. The catalytic tests were carried out at $300^{\circ} \mathrm{C}$ to discriminate the performances among the different samples.

The effect of reaction temperature on catalyst life and catalytic performances are reported in Table 4 for catalyst 1792-212.

Cyclohexanone oxime conversion increases with increasing temperature of reaction and at $400{ }^{\circ} \mathrm{C}$ it is complete, however caprolactam selectivity increases from 85 to $90 \%$ when temperature is raised from $300^{\circ} \mathrm{C}$ to $350^{\circ} \mathrm{C}$, then it decreases to $80 \%\left(400^{\circ} \mathrm{C}\right)$. This phenomenon can be ascribed to (i) a better catalyst activation and (ii) an easier tars desorption from the catalyst surface, nevertheless by increasing the temperature, the thermodynamics of by-product formation is promoted so, at $400{ }^{\circ} \mathrm{C}$, we observe a decrease of caprolactam yield and verify the formation of higher quantities of heavy volatile products. In addition, when temperature is raised from $300^{\circ} \mathrm{C}$ we observe a relevant longer catalyst lifetime. This is attributed to the improvement of catalytic performances and more efficient heavy products desorption.

In order to verify the stability of silicalite- 1 samples, we performed some catalyst regeneration cycles at $450{ }^{\circ} \mathrm{C}$ in air. Such operation is required to eliminate tars adsorbed on catalyst surface, since tars formation occurs mainly on silicalite- 1 external surface. The dimension of silicalite- 1 channels prevents heavy product formation through a shape selective action, thus catalyst deactivation occurs mainly through pores blocking and cavities inaccessibility. This operating condition allows a good catalyst regeneration and remove the organic residues.

Table 4 Effect of reaction temperature on the catalytic activity for 1792-212 sample. Values reported to the fourth hour of reaction

\begin{tabular}{lllll}
\hline $\begin{array}{l}\text { Reaction } \\
\text { temperature } /{ }^{\circ} \mathrm{C}\end{array}$ & $\begin{array}{l}\text { Cyclohexanone } \\
\text { oxime conversion } \\
(\%)\end{array}$ & $\begin{array}{l}\text { Caprolactam } \\
\text { selectivity } \\
(\%)\end{array}$ & $\begin{array}{l}\text { Caprolactam } \\
\text { yield }(\%)\end{array}$ & $\begin{array}{l}\text { Life } \\
\text { time/h }\end{array}$ \\
\hline 300 & 59 & 85 & 50 & $7^{a}$ \\
350 & 98 & 90 & 88 & $40^{b}$ \\
400 & 100 & 80 & 80 & $40^{c}$
\end{tabular}

${ }^{a}$ Cyclohexanone oxime conversion $38 \%{ }^{b}$ Cyclohexanone oxime conversion $75 \%{ }^{c}$ Cyclohexanone oxime conversion $90 \%$. 
Table 5 Catalytic performances for 1793-111 catalyst after one to three regeneration cycles. Catalytic tests are carried out at $350^{\circ} \mathrm{C}$, values are referred to the fourth hour of reaction

\begin{tabular}{lllll}
\hline & Fresh & I cycle & II cycle & III cycle \\
\hline $\begin{array}{l}\text { Cyclohexanone oxime } \\
\text { conversion (\%) }\end{array}$ & 99.9 & 99.9 & 99.9 & 99.9 \\
$\begin{array}{l}\text { Caprolactam } \\
\text { selectivity (\%) }\end{array}$ & 94.0 & 91.8 & 94.0 & 91.3 \\
\hline
\end{tabular}

Catalytic results for sample 1793-111 are rather high and we do not observe any relevant difference between catalytic performances. In table 5 we report the results for catalyst 1793111 after three regeneration cycles with operating temperature $350^{\circ} \mathrm{C}$.

The stability of catalytic activity is attributed to the $\mathrm{Si}-\mathrm{NH}_{2}$ bondings which are co-ordinated to hydroxyl groups and leads to a higher stability of silanol-nests since they are unaltered after thermal treatment in air at $450^{\circ} \mathrm{C}$ for $10 \mathrm{~h}$.

\section{Conclusions}

High silica MFI zeolite lattice is formed by tetrahedral silicon oxides and are characterized by defective sites namely $\mathrm{H}$ bonded silanols (vicinal or nests of silanols) whose amount and distribution is modified by the different thermal treatment and activation methods. By $\mathrm{NH}_{3}$-TPD analysis it is possible to quantify catalysts total acidity and distinguish and quantify different kinds of acid sites. Our silicalite-1 samples show a very weak acidity in the range 7.0-5.0 $\times{ }^{-5} \mathrm{~mol} \mathrm{NH}_{3} \mathrm{~g}^{-1}$ and weak and very weak acid sites. Samples calcined at $450{ }^{\circ} \mathrm{C}$ and activated by an alkaline $\mathrm{NH}_{4} \mathrm{NO}_{3}$ solution are characterized by a relatively higher acidity $\left(7.15 \times^{-5} \mathrm{~mol} \mathrm{~g}^{-1}\right)$ and a higher ratio between weak acid sites and very weak acid sites. Said catalysts are very active in vapor phase Beckmann rearrangement and complete cyclohexanone oxime conversion and caprolactam yield higher than $95 \%$ are achieved. It is also demonstrated that a calcination temperature of $550^{\circ} \mathrm{C}$ promotes H-bonded silanols condensation, hence a decrease of the amount of defective sites and a decrease of catalytic activity.

Catalysts activation with an alkaline solution of $\mathrm{NH}_{4} \mathrm{NO}_{3}$ modifies the unit cell symmetry from monoclinic to orthorhombic through $\mathrm{Si}-\mathrm{NH}_{2}$ bondings formation and allows the retention of a higher $\mathrm{H}$-bonded silanol to terminal silanol ratio. On the basis of structural features and catalytic results we confirmed that Beckmann rearrangement reaction is promoted by H-bonded silanols and especially by silanol nests which are mainly located in the catalyst cavities. Caprolactam selectivity shows a dependence with amounts of silanol nests. Sample 1796 which has been prepared with a low quantity of mineralizing agent shows a ${ }^{29} \mathrm{Si}-\mathrm{MAS}-\mathrm{NMR}$ profile which is not typical of silicalite- 1 structures, in addition its total acidity is lower than that of other catalysts.
Crystals size deeply affects catalytic performances for it modifies the ratio between internal and external surface. Caprolactam selectivity increases with increasing crystal size for -111 samples, whereas cyclohexanone oxime conversion decreases. On the contrary, other samples $(-121,-212,-222)$ show a decrease of both cyclohexanone oxime conversion and caprolactam selectivity and a deactivation rate consistently higher. Such a behavior has been explained by the different acid sites distribution between internal and external surface. As a matter of fact silanol nests which are located in the channels of silicalite-1 undergo a slower deactivation for the small channels dimensions, hinder tars formation through a shape selective activity. Terminal silanols are mainly located at the external surface of the catalysts, promote cyclohexanone oxime non-selective conversion thus they quickly deactivate. After regeneration upon 1793-111 catalyst, the catalytic activity is unchanged for thermal treatment in air removes tars and leaves the silicalite- 1 structure unchanged, we propose that $\mathrm{Si}-\mathrm{NH}_{2}$ bondings give to the silicalite-1 structure a higher thermal stability.

We verified the effect of temperature and we found that for silicalite- 1 at $T=350{ }^{\circ} \mathrm{C}$ the best equilibrium between caprolactam reaction activation energy and minimization of byproducts formation is reached, at this temperature the higher caprolactam yield is obtained and the longer catalyst lifetime achieved.

\section{References}

1 M. Kitamura, H. Hichihashi and I. Tojima, US Pat. 5212302 , 1993.

2 G. P. Heitmann, G. Dahlhoff and W. F. Hölderich, J. Catal., 1999, 186, 12-19.

3 J. N. Armor, Catalysis of Organic Reactions, Chemical Industries, 18, Kosak J.R. Editor.

4 H. Ichiashi and M. Kitamura, Catal Today, 2002, 73, 23-28.

5 J. Ritz, H. Fuchs, H. Kiezka and W. C. Moran, Ullmann's Encyclopedia of Industrial Chemistry, ed. F. T. Campbell et al., VCH, Weinheim, 1986, 5, 31-49.

6 J. N. Armor, Appl. Catal. A, 1999, 189, 153-162.

7 R. A. Sheldon, Appl. Catal. A, 1999, 189, 163-183.

8 C. Flego and L. Dalloro, Microporous Mesoporous Mater., 2003, 60, 263-271.

9 http://www.sumitomo-chem.co.jp/cgi-bin/search/release_2e.cgi? year $=2000$.

10 W. F. Hölderich and G. Dahlhoff, Chem. Innov., 2001, 2, 29-40.

11 Verified Synthesis of Zeolitic Materials, ed. H. Robson, Elsevier, Amsterdam, 2001.

12 Y. S. Ko and W. S. Ahn, Microporous Mesoporous Mater., 1999, 30, 283-291.

13 B. A. Morrow, I. A Cody and L. S. M. Lee, J. Phys. Chem., 1975, 79, 761-762.

14 S. P. Zhdanov, L. S. Kosheleva and T. I. Titola, Langmuir, 1987, 3, 960-967.

15 S. Bordiga, P. Ugliengo, A. Damin, C. Lamberti, G. Spoto, A. Zecchina, G. Spanò, R. Buzzoni, L. Dalloro and F. Rigetti, Top. Catal., 2001, 15, 43-52.

16 G. Centi, S. Pheratoner and F. Trifirò, J. Phys. Chem, 1992, 96, 2617-2629.

17 H. Kath, R. Gläser and J. Weitkamp, Chem. Eng. Technol., 2001, 24, 150-153. 